\section{Differential susceptibility according to gender in the association between air pollution and mortality from respiratory diseases}

\author{
Susceptibilidade segundo sexo na associação \\ entre poluição do ar e mortalidade por \\ doenças respiratórias
}

\author{
Marcio Sacramento de Oliveira 1,2 \\ Antônio Ponce de Leon 3 \\ Inês Echenique Mattos 4 \\ Sérgio Koifman 4
}

\footnotetext{
1 Escola Politécnica de Saúde Joaquim Venâncio, Fundação Oswaldo Cruz, Rio de Janeiro, Brasil.

2 Coordenação de Vigilância Ambiental em Saúde e Saúde do Trabalhador, Secretaria de Estado de Saúde e Defesa Civil do Rio de Janeiro, Rio de Janeiro, Brasil. 3 Instituto de Medicina Social, Universidade do Estado do Rio de Janeiro, Rio de Janeiro, Brasil.

4 Escola Nacional de Saúde Pública Sergio Arouca, Fundação Oswaldo Cruz, Rio de Janeiro, Brasil.

Correspondence M. S. Oliveira Laboratório de Educação Profissional em Vigilância em Saúde, Escola Politécnica de Saúde Joaquim Venâncio, Fundação Oswaldo Cruz. Av. Brasil 4365, Rio de Janeiro, RJ 21045-900, Brasil. marcio.sacramento@saude. rj.gov.br
}

\section{Abstract}

This study analyzed the association between air pollution and deaths from respiratory diseases, considering differential susceptibility according to gender. The authors used daily deaths from respiratory diseases (ICD-10, J00-J99), $\mathrm{PM}_{10}, \mathrm{SO}_{2}$, and $\mathrm{O}_{3}$ levels, and meteorological indicators in Volta Redonda, Rio de Janeiro State, Brazil, from January 2002 to December 2006. The association was estimated by Poisson regression using generalized additive models, where the increase in risk of deaths from $P M_{10}$ to lag 1 was $10.01 \%$ (95\%CI: $1.81-18.88 \%)$ in the total female population and 10.04\% (95\%CI: 0.90-20.02\%) in elderly women. The increase in risk of deaths from $P M_{10}$ to lag 9 was $8.25 \%$ in the total male population (95\% CI: 0.86-16.18\%) and $10.80 \%$ (95\%CI: 2.18-20.15\%) in elderly men. For exposure to $\mathrm{SO}_{2}$ and $\mathrm{O}_{3}$, the risk was significant in the total male population and the elderly, respectively. The results emphasize the need for further studies, focusing on modification of the effects of air pollution on health.

Air Pollution; Respiratory Tract Diseases; Disease Susceptibility; Mortality

\section{Introduction}

Rapid technological progress in the modern world has produced an increase in the amount and variety of air pollutants, thereby jeopardizing the quality of life on the planet 1,2 . Air pollution has been considered a serious public health problem for some time, acting as an additional health risk factor for humans, animals, and plants 3 .

As an example of air pollution, particulate matter accounts for approximately $3 \%$ of annual mortality from cardiopulmonary diseases in adults, $5 \%$ of mortality from cancer of the trachea, bronchi, and lungs, and $1 \%$ of child mortality from acute respiratory infections in urban areas of the world 4 .

Recent epidemiological studies provide evidence of the association between different health outcomes and increased daily air pollution levels, especially in more susceptible population groups like children, elderly, and individuals with cardiorespiratory diseases. The majority of these studies have been conducted in large urban areas, especially in the United States and Europe 5,6,7,8,9,10,11, but little is known about the magnitude of the relative impacts of these pollutants on Brazilian cities, where the studies are concentrated mostly in Rio de Janeiro, São Paulo, and Curitiba 12,13,14,15,16,17. Outside the large Brazilian cities, there has been an increase in the number of studies in the North (Acre State) and Central-West (Mato Grosso and Tocantins 
States), concerning the impact of burning biomass on the population's health, conducted by the State Health Departments with encouragement from the Brazilian Ministry of Health, through the Program for Environmental Health Surveillance and Air Quality (VIGIAR), as a strategy for orienting the development of its work, allowing integration of health services and fostering comprehensive actions.

The few studies reporting on health effects of exposure to air pollution due to gender-related differences in susceptibility have been inconclusive and have generally not been designed for this purpose 18,19 .

$\mathrm{Kim} \& \mathrm{Hu} 20$ found that in females, depending on the diameter of the inhaled particles, there was a greater deposition in the upper airways and tracheobronchial and alveolar regions, and that for ultrafine particles, this deposition was more localized and higher in female pulmonary alveoli, suggesting that this can lead to a greater risk of development of respiratory problems in women. These findings are consistent with the hypothesis that greater deposition of particles in the lungs can cause an alveolar inflammatory response, promoting the exacerbation of lung diseases and thus increased susceptibility 21 . Meanwhile, Bennett et al. 22 and Daigle et al. 23 found in their studies that men and women display similar deposition of fine and ultrafine particles in the airways.

Studies thus far have shown conflicting results, so that this is still an open question. Therefore, the current study aimed to assess the association between daily exposure to air pollutants and mortality from diseases of the respiratory system, considering differential susceptibility by gender for all deaths and for those in the elderly.

\section{Material and methods}

\section{Study area}

Volta Redonda is a municipality (county) located at 22.31'23" latitude South and 4406'15" longitude West in the Vale do Paraíba micro-region, within the Sul Fluminense meso-region in the State of Rio de Janeiro, Brazil. The municipality's total area is $182.8 \mathrm{~km}^{2}$, of which $54 \mathrm{~km}^{2}$ comprise the city limits of the municipal seat. Accompanying the Paraíba do Sul river, which cuts through the city of Volta Redonda from Southwest to East, the urban area is located along the banks of the river on a plain surrounded by hills whose altitude varies from 350 meters above sea level along the river to 707 meters at the northeastern tip. According to the National Census Bureau, or
Brazilian Institute of Geography and Statistics (IBGE), the total population in 2009 was 261,403 . Volta Redonda has a mesothermal climate and high relative humidity $(77 \%)$, even in the cooler months, when it varies from $71 \%$ to $72 \%$. The adjusted mean temperature is $21^{\circ} \mathrm{C}$, with a mean annual low of $16.5^{\circ} \mathrm{C}$ and mean annual high of $27.8^{\circ} \mathrm{C}$. Mean annual precipitation is $1,377.9 \mathrm{~mm}$, and January and February are the months with the heaviest rainfall. Considered the economic hub of the Sul Fluminense meso-region, the economy of Volta Redonda, although still anchored in industry, is quite diversified, focused to a major extent on services and commerce. The municipality is home to the large steel mill Companhia Siderúrgica Nacional (CSN) and other smaller industries, the Votoran (Votorantim Group) and Tupi (Cimento e Participações - CP) cement factories, the White Martins Oxygen and Nitrogen Plant, the flat steel products company Industria Nacional de Aços Laminados (INAL), the tin mill Companhia Estanifera Brasileira (CESBRA), and S/A Tubonal (steel pipes) (Portal VR. http://www.voltaredonda.rj.gov.br/cidade/ índex.php, accessed on 12/May/2010).

\section{Study design}

This was an ecological time series study conducted in the Municipality of Volta Redonda from January 1, 2002, to December 31, 2006.

\section{Data collection}

Daily reports of deaths from diseases of the respiratory system (ICD-10, J00-J99) were obtained from the Mortality Information System, Ministry of Health (SIM).

Daily records of mean concentrations of particulate matter with aerodynamic size up to 10 $\mathrm{m}\left(\mathrm{PM}_{10}\right)$, sulfur dioxide $\left(\mathrm{SO}_{2}\right)$, ozone $\left(\mathrm{O}_{3}\right)$, low temperature, and mean relative humidity (RH) were provided by the Rio de Janeiro State Environmental Institute (INEA) from automatic air quality monitoring stations located in Volta Redonda in the following neighborhoods: Jardim Belmonte (west side), Vila Santa Cecília (north side), and Retiro (city center).

The daily averages for the environmental variables from the three stations were calculated after imputing missing data using the modified expectation maximization (EM) algorithm, applied under the assumptions of multivariate normal distribution. In addition to the inter-variable dependency structure, this method also considers the time dependency structures for each variable. The time component contribution of each univariate series was estimated ad hoc, that is, 
additional models were needed for estimating $\mu_{\mathrm{t}}$. In this imputation method, the non-parametric cubic spline was implemented to estimate the time series level 24 .

According to the report on the implementation of the INEA environmental monitoring network in Volta Redonda, the monitoring network's spatial configuration provides a correlation between the stations' measurements and coverage of the pollutants with at least $70 \%$ efficiency.

\section{Data analysis}

Initially, we determined the descriptive statistical measurements (arithmetic mean, standard deviation, and minimum and maximum values) for the variables total deaths from diseases of the respiratory system and for the elderly only (defined here as individuals 65 years or older), stratified by gender, and for $\mathrm{PM}_{10}, \mathrm{SO}_{2}, \mathrm{O}_{3}$, low temperature, and RH. In the time series analysis, the daily counts of total deaths and deaths in the elderly, stratified by gender, were considered dependent variables $\left(\mathrm{Y}_{\mathrm{t}}\right)$ and the mean daily concentrations of $\mathrm{PM}_{10}, \mathrm{SO}_{2}$, and $\mathrm{O}_{3}$, one-by-one, were the independent variables $\left(\mathrm{X}_{\mathrm{t}}\right)$. The following control variables were also considered: days of the week (an indicative variable for each day of the week, in order to control the calendar effect), time (variable sequence 1 after the last day of the study period, to adjust seasonality and long-term tendency), national and local holidays (an indicative variable for each type of holiday), and mean daily low temperature $\left({ }^{\circ} \mathrm{C}\right)$ and $\mathrm{RH}(\%)$ (used to adjust for climatic factors).

In relation to the dependent variable and some control variables, such as meteorological variables, which are not necessarily linear, generalized additive models (GAM) 25 using Poisson regression with non-parametric functions of the cubic smoothing spline type were applied to estimate the association between daily deaths from diseases of the respiratory system and daily levels of these meteorological indicators. Importantly, the smoother is a function of $\mathrm{x}$ and $\mathrm{y}$ with the same $\mathrm{x}$ domain, defined for every point $\mathrm{x}_{0}$ or sometimes only for the $x_{i}$ of the sample. For each $x_{i}$ value, the smoother associates a value $f\left(x_{i}\right)$, the $\hat{f}\left(x_{i}\right)$ estimate of which can be obtained. By definition, the values of this function should be "smoother" than the y values, i.e., they should have a lower variability than the y values 26 . The smoothing procedure was used for time and for the meteorological variables, in order to adjust the trend and both the basic and more long-term seasonal patterns.

After adjusting the dependent variable for the control factors, the independent variables were inserted one-by-one into the models. Since the biological manifestations of the effects of air pollution on health outcomes apparently display a lag type behavior in individual exposure to pollutants 27 , the dependent variables were inserted with a lag time of zero to 10 days, one by one, considering the day after exposure, in order for a more precise definition of the model to be used.

The final model's goodness of fit was estimated by residuals analysis and the Akaike information criterion (AIC) 28 . The relative risks (RR) for deaths corresponded to a $10 \mu \mathrm{g} / \mathrm{m}^{3}$ increase in the concentration of air pollutants and $5 \%$ level of significance. The data were analyzed with the R software, version 2.12.0, with the ARES statistical library, version 0.7.0 (The R Foundation for Statistical Computing, Vienna, Austria; http:// www.r-project.org).

\section{Results}

During the study period, which covered 1,826 days, there were 8,518 deaths in the municipality of Volta Redonda, of which 1,058 (12.4\%) were due to respiratory diseases. Of these, 788 (74.5\%) occurred in elderly individuals (Table 1).

The total number of respiratory deaths in the population varied from 0 to 4 per day. Among the elderly, after stratifying by gender, this figure varied from 0 to 3 deaths (Table 1). The data showed a downward trend in mortality from respiratory diseases in most of the study period. This trend remained stable among women, while among men there was an increase beginning in the winter of 2005.

During the study period, $75 \%$ of the mean concentrations of daily $\mathrm{PM}_{10}$ emissions remained below $35.95 \mu \mathrm{g} / \mathrm{m}^{3}$, and the highest concentration was $122.70 \mu \mathrm{g} / \mathrm{m}^{3}$ (Table 1 ), with an annual mean of $30.56 \pm 12.16 \mu \mathrm{g} / \mathrm{m}^{3}$, thus below the $50 \mu \mathrm{g} / \mathrm{m}^{3}$ emissions standard. Air pollution emission standards were set in Brazil by the National Environmental Board (CONAMA) under Ruling 003/1990.

The smoothing curve for the $\mathrm{PM}_{10}$ temporal distribution showed a seasonal pattern, with an increase in daily emissions during the "winter" (or cool season) and a decrease in the summer, showing a downward trend during most of the study period and a constant trend at the end; $\mathrm{SO}_{2}$ showed a similar pattern, but with less variation. $\mathrm{O}_{3}$ showed an erratic behavior, with stability in terms of seasonality and trend from the beginning of the period until September 2004, a downward trend until April 2005, and an upward trend since then (Figure 1). $\mathrm{PM}_{10}$ and $\mathrm{SO}_{2}$ did not display any violation of the daily emission 
Descriptive analysis of the daily count of total deaths from diseases of the respiratory system (ICD-10: J00-99) and in the elderly, stratified by gender, daily air pollution measurements, and meteorological variables. Volta Redonda, Rio de Janeiro State, Brazil, 2002-2006.

\begin{tabular}{|c|c|c|c|c|c|c|c|c|}
\hline \multirow[t]{2}{*}{ Variables } & \multicolumn{8}{|c|}{ Descriptors } \\
\hline & $\mathrm{n}$ & $\%$ & Days & Missing & Mean & SD & Minimum & Maximum \\
\hline Total deaths & 1,058 & 100.00 & 1,826 & 0 & 0.58 & 0.75 & 0.00 & 4.00 \\
\hline Females & 512 & 48.40 & 1,826 & 0 & 0.28 & 0.51 & 0.00 & 3.00 \\
\hline Males & 546 & 51.60 & 1,826 & 0 & 0.30 & 0.54 & 0.00 & 3.00 \\
\hline$\geq 65$ years & 788 & 100.00 & 1,826 & 0 & 0.58 & 0.75 & 0.00 & 4.00 \\
\hline Females $\geq 65$ years & 400 & 50.76 & 1,826 & 0 & 0.22 & 0.45 & 0.00 & 3.00 \\
\hline Males $\geq 65$ years & 388 & 49.24 & 1,826 & 0 & 0.21 & 0.46 & 0.00 & 3.00 \\
\hline $\mathrm{PM}_{10}\left(\mu \mathrm{g} / \mathrm{m}^{3}\right)$ & - & - & 1,807 & 19 & 30.56 & 12.16 & 7.58 & 122.70 \\
\hline $\mathrm{SO}_{2}\left(\mu \mathrm{g} / \mathrm{m}^{3}\right)$ & - & - & 1,794 & 32 & 9.04 & 5.11 & 0.00 & 56.50 \\
\hline $\mathrm{O}_{3}\left(\mu \mathrm{g} / \mathrm{m}^{3}\right)$ & - & - & 1,790 & 36 & 59.16 & 25.45 & 6.55 & 171.70 \\
\hline Relative humidity (\%) & - & - & 1,763 & 63 & 81.05 & 8.76 & 51.04 & 99.60 \\
\hline Low temperature $\left({ }^{\circ} \mathrm{C}\right)$ & - & - & 1,790 & 36 & 18.39 & 3.26 & 7.37 & 25.45 \\
\hline
\end{tabular}

standards, set respectively at $150 \mu \mathrm{g} / \mathrm{m}^{3}$ and $100 \mu \mathrm{g} / \mathrm{m}^{3} . \mathrm{O}_{3}$ showed three violations of the standard $\left(161.30,162.10\right.$, and $\left.171.70 \mu \mathrm{g} / \mathrm{m}^{3}\right)$, which was set at $160 \mu \mathrm{g} / \mathrm{m}^{3}$.

The mean values for relative humidity and low temperature were, respectively, $81.05 \pm 8.76 \%$ and $18.39 \pm 3.26^{\circ} \mathrm{C}$ (Table 1 ).

Figure 2 shows the estimated risk of respiratory deaths due to a $10 \mu \mathrm{g} / \mathrm{m}^{3}$ increase in $\mathrm{PM}_{10}$, $\mathrm{SO}_{2}$, and $\mathrm{O}_{3}$ levels in Volta Redonda. In the first three days after exposure, one can expect, respectively, an increase of $10.01 \%$ (95\%CI: 1.81 $18.88 \%$; p-value $=0.02), 8.56 \%(95 \% \mathrm{CI}: 0.77$ $16.95 \%$; p-value $=0.03)$, and $9.37 \%(95 \% \mathrm{CI}: 1.72$ $17.60 \%$; $p$-value $=0.01$ ) in the risk of deaths due to respiratory diseases in the total female population. In women 65 years or older, the increase in risk on the first, third, and fourth days was $10.04 \%$ (95\%CI: $0.90-20.02 \%$; p-value $=0.03$ ), $10.57 \%$ (95\%CI: 1.95-19.92\%; p-value $=0.01$ ), and $9.27 \%$ (95\%CI: 0.66-18.61\%; p-value $=0.03$ ), respectively. The risk of death in women was not statistically significant for the other air pollutants (Figure 2).

For the total male population, as well as for men 65 years or older, with a nine-day lag after exposure to $\mathrm{PM}_{10}$, one can expect an increase in risk of deaths of $8.25 \%$ (95\%CI: $0.86-16.18 \%$; pvalue $=0.03$ ) and $10.80 \%$ (95\%CI: $2.18-20.15 \%$; $\mathrm{p}$-value $=0.01$, respectively.

For exposure to $\mathrm{SO}_{2}$, the effect in the total male population showed a two-day lag and increased risk of $20.25 \%$ (95\%CI: $0.41-44.01 \%$; value $=0.04)$. In elderly men, no association was observed between $\mathrm{SO}_{2}$ levels and the outcome. However, on the ninth day after exposure to $\mathrm{O}_{3}$, the increase in risk of death was $5.88 \%$ (95\%CI: $0.89-11.12 \%$; $\mathrm{p}$-value $=0.02$ )

As for $\mathrm{PM}_{10}$, besides differences in effect sizes between women and men, the effect of exposure to the pollutant on respiratory deaths occurred later in men, while in women it occurred beginning on the first day after exposure (Figures 2 and 3).

\section{Discussion}

There has been an increase in the number of epidemiological studies on the association between air pollution and a wide variety of health outcomes. These include studies on the effects on overall mortality and that due to specific causes such as cardiovascular and respiratory diseases 12,13,14,15,18,19,27,29,30,31,32,33.

According to Castro et al. ${ }^{3}$, one of the main advantages of time series analyses is that factors such as socioeconomic status, occupation, or smoking are not capable of confounding the relationship between air pollution and health effects, since these factors do not display significant daily variations. Meanwhile, factors with such variation and that correlate with pollution are potential confounders and should be adjusted in the analysis. Factors that underwent such adjustment in the current study included meteorological variables (temperature and humidity) and chronological factors such as days of the week 
Temporal distribution of daily concentrations and smoothing curve for $\mathrm{PM}_{10}, \mathrm{SO}_{2}$, and $\mathrm{O}_{3}$. Volta Redonda, Rio de Janeiro State, Brazil, 2002-2006.

1a) $\mathrm{PM}_{10}$ concentration

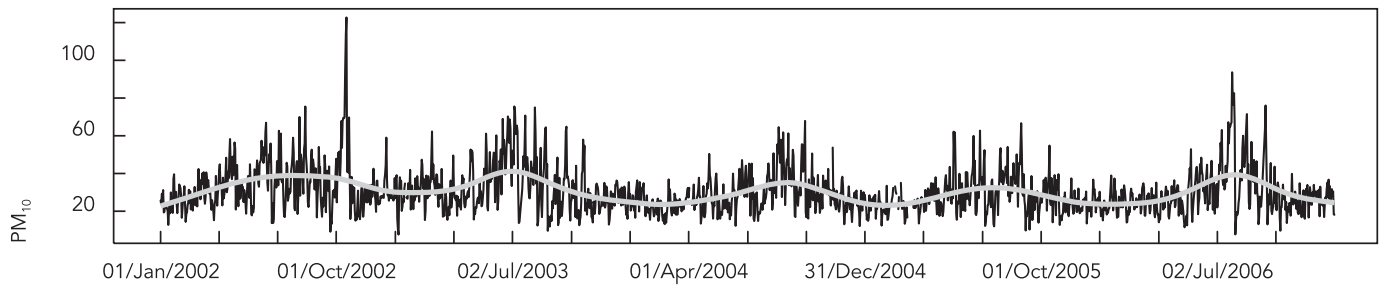

1b) $\mathrm{SO}_{2}$ concentration

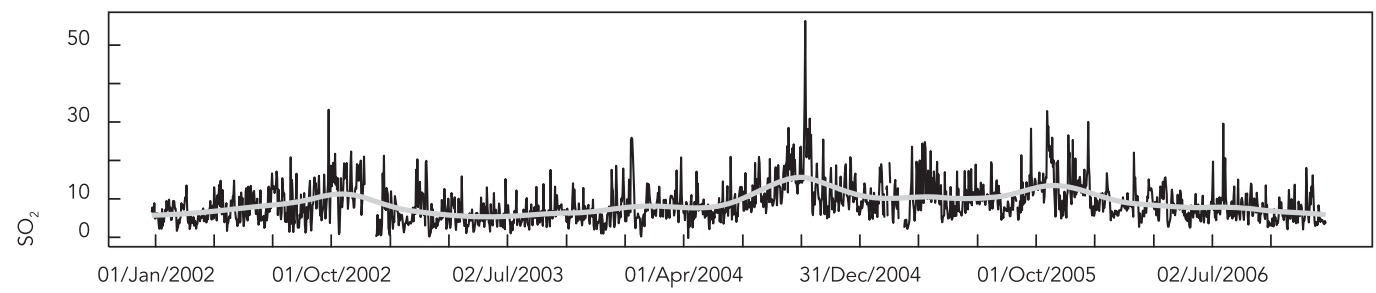

1c) $\mathrm{O}_{3}$ concentration

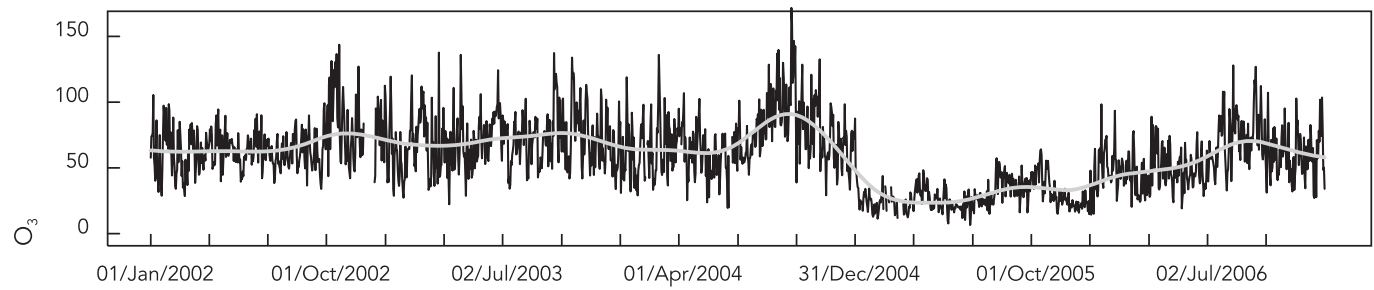

(variable for adjusting the calendar effect), total number of days transpired in the study period (variable for adjusting long-term seasonality), and holidays.

The study results may not have suffered any influence from differences (since they were small) in the proportion of women in the sample from Volta Redonda or in the percentages of deaths. Thus, the extrinsic factors that might have affected the observed results and that were not possible to determine with the methodology were the prevalence of some respiratory conditions that would explain the greater effect size for $\mathrm{PM}_{10}$ and the absence of a significant effect from the other pollutants in women, as well as a more rapid physiological response to exposure in the outcome's manifestation as compared to men, or even a different spatial distribution of women over the course of the day as compared to men, exposing them to the pollutants' impact for most of the day.

The use of GAM allowed to more effectively control the confounding factors (trend, seasonality, cycle, temperature, humidity, holidays, and calendar effect), which could interfere in the data analysis. GAM was chosen as the study's analytical tool because the model allows adjusting non-parametric functions for variables presenting this behavior, thus minimizing possible errors in the effect estimates and their respective standard errors. Poisson regression was used, since it allowed analyzing the counting 
For deaths from respiratory diseases, percentage of relative risk for total female deaths and deaths in elderly women related to a $10 \mu \mathrm{g} / \mathrm{m}^{3}$ increase in daily $\mathrm{PM}_{10}, \mathrm{SO}_{2}$, and $\mathrm{O}_{3}$ levels. Volta Redonda, Rio de Janeiro State, Brazil, 2002-2006.

2a) Pollutant: $\mathrm{PM}_{10}$ for total female deaths

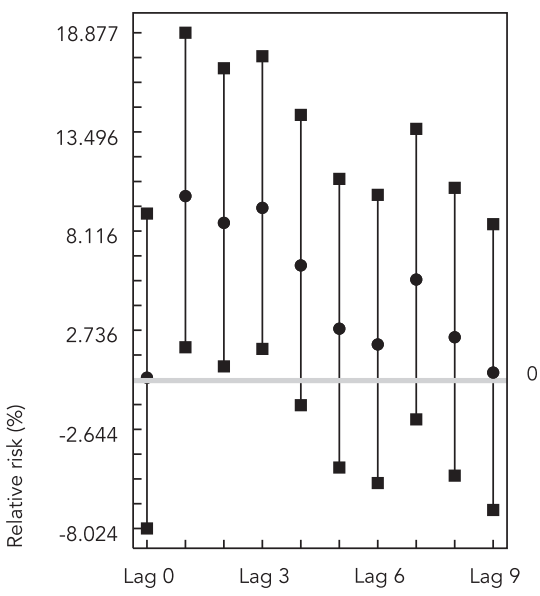

2d) Pollutant: $\mathrm{PM}_{10}$ for deaths in elderly women

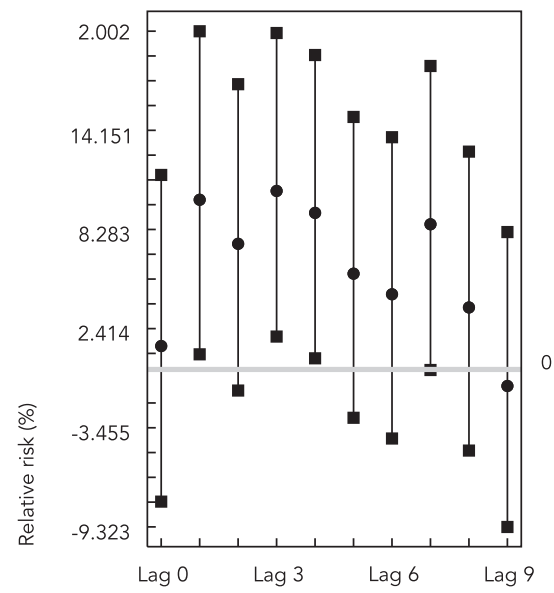

2b) Pollutant: $\mathrm{SO}_{2}$ for total female deaths

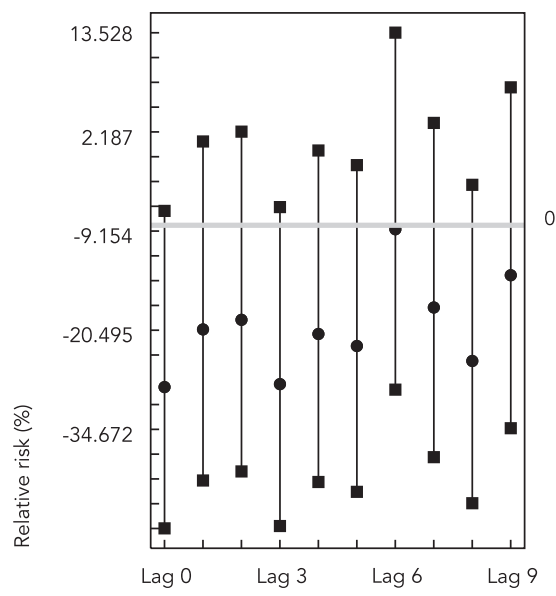

2e) Pollutant: $\mathrm{SO}_{2}$ for deaths in elderly women

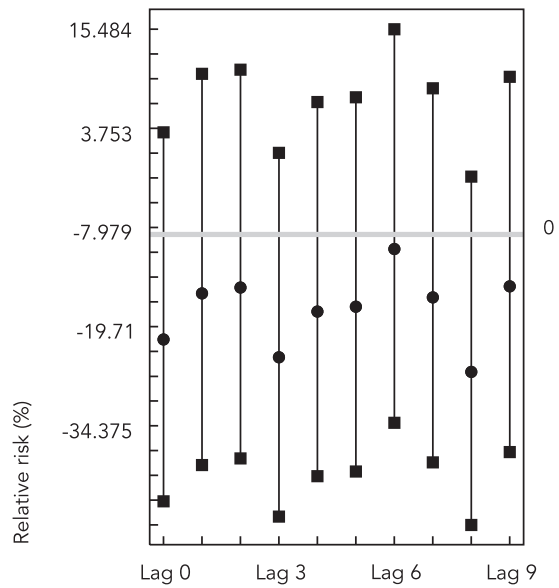

2c) Pollutant: $\mathrm{O}_{3}$ for total female deaths

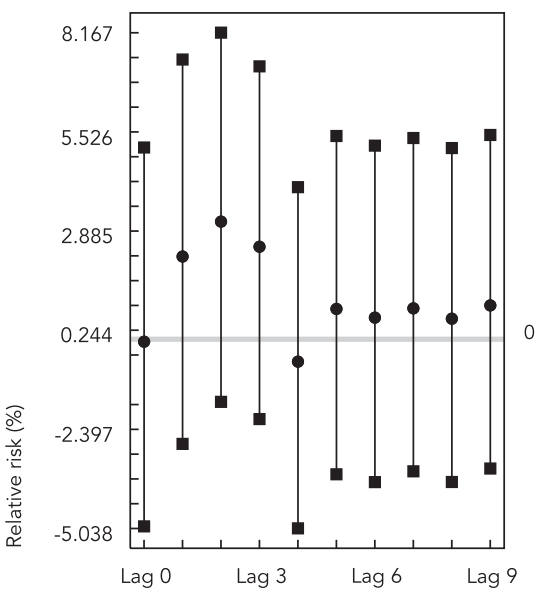

2f) Pollutant: $\mathrm{O}_{3}$ for deaths in elderly women

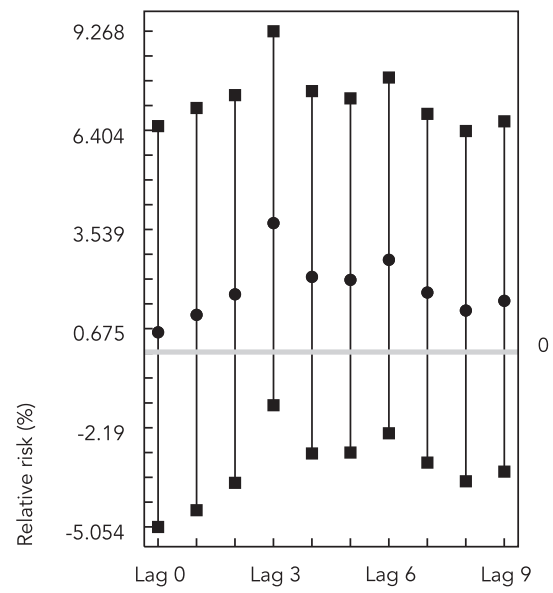

data, the daily number of deaths from respiratory diseases.

Analysis of the data's temporal distribution showed marked seasonality in the $\mathrm{PM}_{10}$ and $\mathrm{SO}_{2}$ levels, increasing in the winter and decreasing in the summer (Figure 1). This can be explained by the characteristics of the mesothermal climate in the municipality of Volta Redonda, with hot, rainy summers and dry winters, where January and February have the heaviest rainfall. Volta Redonda has northwest prevailing winds, but the fact that it is located in the bottom of a valley means that the air is calm most of the time, thus hindering the dispersion of gases and particles. This process is intensified due to the thermal inversion phenomenon, common in the winter, when the pollution layer hangs over the city, forming a barrier to sunlight, decreasing insolation, and preventing the release of heat and new pollution emissions (Portal VR. http://www.vol taredonda.rj.gov.br/cidade/index.php, accessed on 12/May/2010). 
For deaths from respiratory diseases, percentage of relative risk for total male deaths and deaths in elderly men related to a $10 \mu \mathrm{g} / \mathrm{m}^{3}$ increase in daily $\mathrm{PM} / 0$, $\mathrm{SO}_{2}$, and $\mathrm{O}_{3}$ levels. Volta Redonda, Rio de Janeiro State, Brazil, 2002-2006.

3a) Pollutant: $\mathrm{PM}_{10}$ for total male deaths

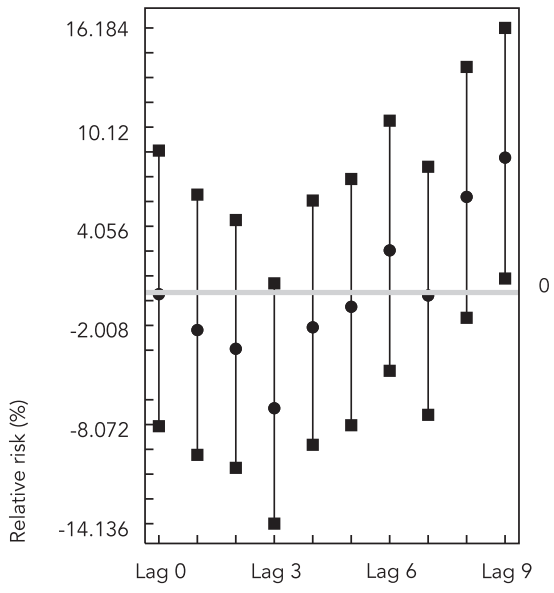

3d) Pollutant: $\mathrm{PM}_{10}$ for deaths in elderly men

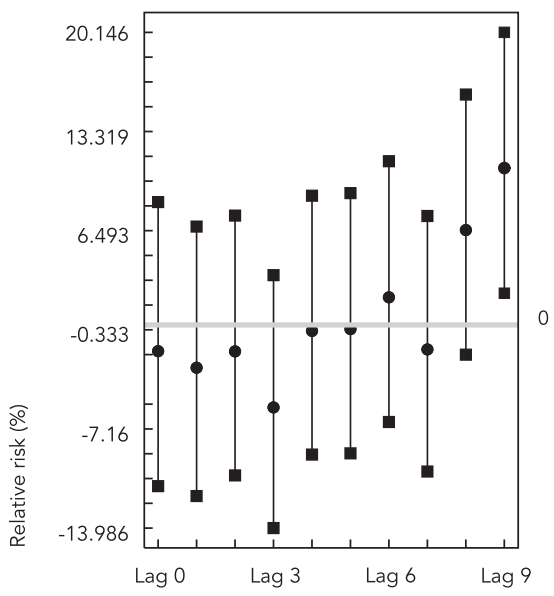

3b) Pollutant: $\mathrm{SO}_{2}$ for total male deaths

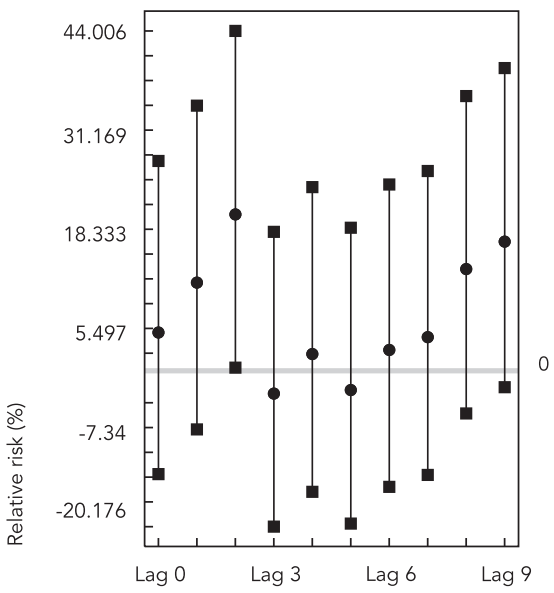

3e) Pollutant: $\mathrm{SO}_{2}$ for deaths in elderly men

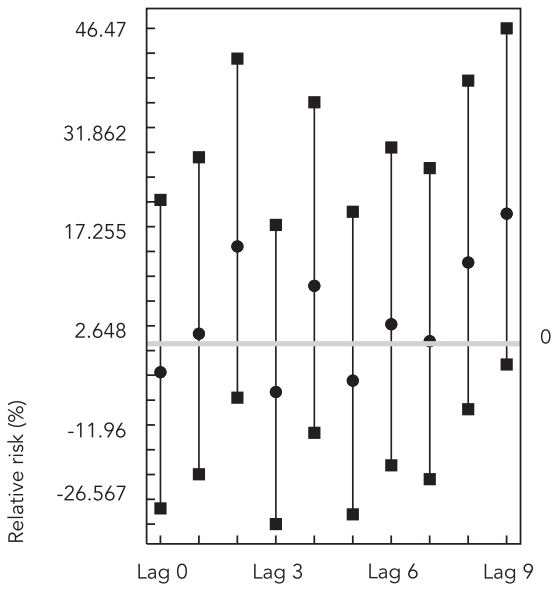

3c) Pollutant: $\mathrm{O}_{3}$ for total male deaths

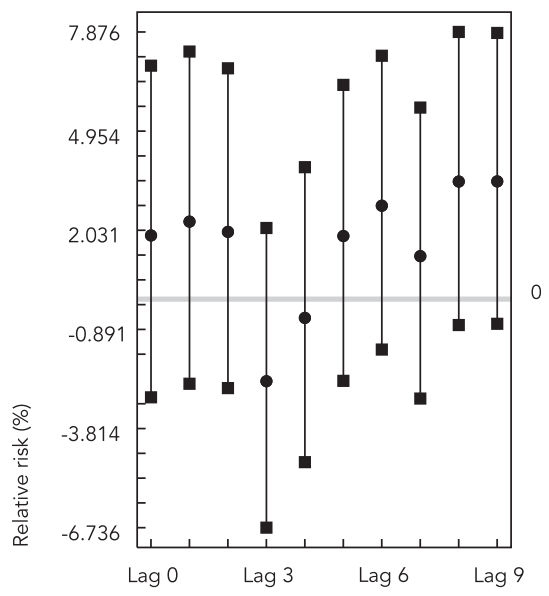

3f) Pollutant: $\mathrm{O}_{3}$ for deaths in elderly men

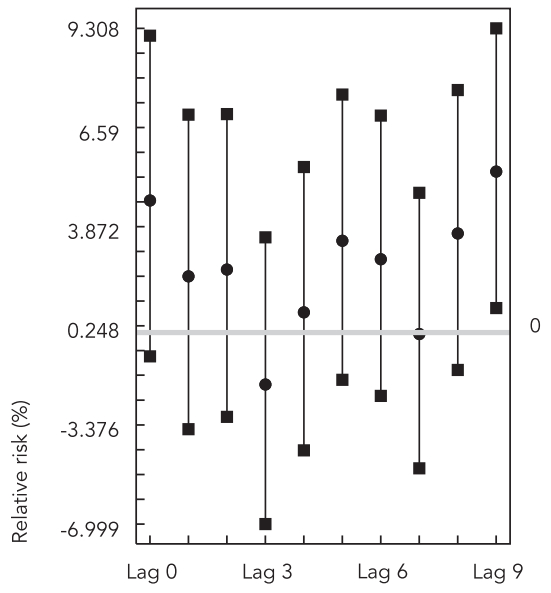

This study's findings suggest a direct association between daily variations between $\mathrm{PM}_{10}$ and $\mathrm{SO}_{2}$ levels and deaths from respiratory diseases, with higher risk size among the elderly (Figures 2 and 3). These results corroborate those of other epidemiological studies, suggesting that increases in mortality associated with air pollution are greater among the elderly, and point to an increase in prevalence of chronic obstructive pulmonary disease (COPD) and other diseases of the airways in this population group, which could also be a determinant of susceptibility 7,31,34.
Physiological changes associated with aging explain the greater susceptibility of the elderly to the effects of PM. All components of the respiratory system are normally affected by aging, including spirometry, oxygen diffusion capacity, lung elasticity, chest wall expansion capacity, respiratory muscle strength, maximum oxygen uptake, and peak cardiac output 7 . The elderly are also more susceptible to respiratory infections, in part due to an age-related decline in the specific immune response, ciliary function, and cough reflex $7,32,33$. 
The increased susceptibility of elderly to particulate matter may also be to due lifelong exposure to environmental substances that are harmful to health, as well as to previous respiratory infections, as observed by Meyer et al. 35 in a study of healthy non-smokers from 65 to 78 years of age. The authors observed an increase in neutrophils, immunoglobulins (IgG, IgA, and IgM), and interleukin-6 (IL-6) in fluid from bronchoalveolar lavage, as compared to samples from individuals 20 to 36 years of age. For the age group 65 years and older, one can assume a high prevalence of chronic respiratory diseases. This could explain the "harvesting" pattern observed in the increase in deaths from this cause, since in this case, exposure to air pollutants would mainly affect a more susceptible and/or vulnerable population subgroup on days following exposure to higher levels of the pollutant. Importantly, given the harvesting phenomenon, the negative (or protective) effects of pollutants can already occur just a few days after exposure. However, if for the existing pollution levels, the size of the susceptible group does not undergo major changes over time, the harvesting phenomenon will not have a great impact in decreasing the number of susceptible individuals, and thus it will still be possible to observe the effects of pollutants after several days of exposure.

The current study showed differences in the size effect between the elderly and the overall population, as well as between genders. As mentioned in this study, although most epidemiological studies on this theme were not conducted specifically for this purpose, some studies report not having observed differences in effect size between genders, while others suggest that exposure to air pollution can affect men and women differently.

Pope et al. 18 found that more polluted cities in the United States showed slightly higher (but not statistically significant) risk of mortality from cardiopulmonary disease in non-smoking women as compared to non-smoking men, when compared to less polluted cities $(\mathrm{RR}=1.57$ in females and $\mathrm{RR}=1.24$ in males). Frampton et al. 19 examined the respiratory effects of exposure to ultrafine carbon particles in healthy and asth- matic men and women. Although some outcomes showed small differences between genders, such as a reduction in peripheral blood monocytes and T-lymphocyte activation in healthy women, the overall results did not allow concluding that there are differences in susceptibility between men and women.

Measurable gender differences in immune and inflammatory responses could also explain the greater female susceptibility; for example, women have a higher CD4+:CD8+ lymphocyte ratio than men, and their peripheral blood monocytes produce more prostaglandin $\mathrm{E}_{2}\left(\mathrm{PGE}_{2}\right)$ and less tumor necrosis factor $\alpha(\mathrm{TNF}-\alpha)$ when stimulated 36,37 .

Thus far, there is not sufficient evidence to rule out the possibility that gender may be related to health risk size from exposure to air pollution. Physiological differences between men and women suggest a possible difference in the response to given levels and especially to different chemical compositions of air pollutants. The current study showed different gender patterns in the trend, size effect, and lag time after exposure. These results emphasize the need for further studies focusing on modification of the effect of air pollution on human health, considering gender as a probable factor in susceptibility to the occurrence of death following exposure to air pollutants, especially in individuals older than 65 years.

\section{Conclusions}

In Volta Redonda, the highest concentrations of pollutants (except $\mathrm{O}_{3}$ ) and deaths from respiratory diseases occurred in the coolest months. Daily $\mathrm{PM}_{10}$ and $\mathrm{SO}_{2}$ emissions were associated with mortality from respiratory diseases, even when emissions were within or close to the standards set by the CONAMA. The association was stronger in women, especially among the elderly, and showed a later effect on the outcome in men as compared to women. The risk of deaths tended to increase in men as time after exposure increased, while the opposite was observed in women from the same age bracket. 


\section{Resumo}

O estudo avaliou a associação entre poluição do ar e óbitos por doenças respiratórias, considerando susceptibilidade diferencial segundo sexo. Foram utilizados óbitos diários por doenças respiratórias (CID-10, J00J99), níveis de $\mathrm{PM}_{10}, \mathrm{SO}_{2}, \mathrm{O}_{3}$ e indicadores meteorológicos de Volta Redonda, Rio de Janeiro, Brasil, de janeiro de 2002 a dezembro de 2006. A associação foi estimada por MAG de regressão de Poisson, onde para lag 1, o aumento do risco dos óbitos por PM ${ }_{10}$ foi de 10,01\% (IC95\%: 1,81-18,88\%) no total da população feminina e 10,04\% (IC95\%: 0,90-20,02\%) em idosas. No total da população masculina, para lag 9, o aumento do risco de óbitos por $P M_{10}$ foi de 8,25\% (IC95\%: 0,86-16,18\%) e de 10,80\% (IC95\%: 2,18-20,15\%) para os idosos. Para exposição ao $\mathrm{SO}_{2}$ e $\mathrm{O}_{3}$, o risco foi significativo no total da população masculina e em idosos respectivamente. Os resultados reforçam a necessidade de estudos adicionais, centrando-se na modificação dos efeitos da poluição do ar sobre a saúde.

Poluição do Ar; Doenças Respiratórias; Suscetibilidade a Doenças; Mortalidade

\section{Contributors}

M. S. Oliveira was responsible for the study design, literature search, data collection and analysis, interpretation of the findings, and writing of the article. A. Ponce de Leon contributed to the data analysis and writing of the article. I. E. Mattos participated in the study design, interpretation of the findings, and writing of the article. S. Koifman participated in the study design, interpretation of the findings, and writing of the article.

\section{References}

1. Hales S, Howden-Chapman P. Effects of air pollution on health. BMJ 2007; 335:314-5.

2. Golub A, Strukova E. Evaluation and identification of priority air pollutants for environmental management on the basis of risk analysis in Russia. J Toxicol Environ Health 2008; 71:86-91.

3. Castro HA, Gouveia N, Escamilla-Cejudo JA. Questões metodológicas para a investigação dos efeitos da poluição do ar na saúde. Rev Bras Epidemiol 2003; 6:135-49.

4. Cohen AJ, Anderson HR, Ostra B, Pandey KD, Krzyzanowski M, Künzli N, et al. The global burden of disease due to outdoor air pollution. J Toxicol Environl Health 2005; 68:1-7.

5. Ward DJ, Ayres JG. Particulate air pollution and panel studies in children: a systematic review. Occup Environ Med 2004; 61:2-13.
6. Filleul L, Rondeau V, Vandentorren S, Lê Moual N, Cantagrel A, Annesi-Maesano I, et al. Twenty-five year mortality and air pollution: results from the French PAARC survey. Occup Environ Med 2005; 62:453-60.

7. World Health Organization. Air quality guidelines - global update 2005. Rheinbach: World Health Organization; 2006.

8. Jacobson MZ. Effects of ethanol (E85) versus gasoline vehicles on cancer and mortality in the United States. Environ Sci Technol 2007; 41:4150-7.

9. Moreno T, Querol X, Alastuey A, Ballester F, Gibbons W. Airborne particulate matter and premature deaths in urban Europe: the new WHO guidelines and the challenge ahead as illustrated by Spain. Eur J Epidemiol 2007; 22:1-5. 
10. Ostro B, Broadwin R, Green S, Feng WY, Lipsett M. The effects of components of fine particulate air pollution on mortality in California: results from CALFINE. Environ Health Perspect 2007; 115:13-9.

11. Bell ML, Dominici F. Effect modification by community characteristics on the short-term effects of ozone exposure and mortality in 98 US communities. Am J Epidemiol 2008; 167:986-97.

12. Saldiva PHN, Lichtenfels AJFC, Paiva PSO, Barone IA, Martins MA, Massad E, et al. Association between air pollution and mortality due to respiratory diseases in children in São Paulo: a preliminary report. Environ Res 1994; 65:218-25.

13. Bakonyi SMC, Danni-Oliveira IM, Martins LC, Braga ALF. Poluição atmosférica e doenças respiratórias em crianças na cidade de Curitiba, PR. Rev Saúde Pública 2004; 38:695-700.

14. Junger WL, Leon AP, Mendonça GAS. Associação entre mortalidade diária por câncer de pulmão e poluição do ar no município do Rio de Janeiro: um estudo ecológico de séries temporais. Rev Bras Cancerol 2005; 2:111-5.

15. Castro HA, Cunha MF, Mendonça GAS, Junger WL, Cunha-Cruz J, Leon AP. Efeitos da poluição do ar na função respiratória de escolares, Rio de Janeiro, RJ. Rev Saúde Pública 2009; 43:26-34.

16. Nascimento LFC, Pereira LAA, Braga ALF, Módolo MCC, Carvalho JA. Efeitos da poluição atmosférica na saúde infantil em São José dos Campos, SP. Rev Saúde Pública 2006; 40:77-82.

17. Nascimento LFC, Módolo MCC, Carvalho JA. Atmospheric pollution effects on childhood health: an environmental study in the Paraíba Valley. Rev Bras Saúde Matern Infant 2004; 4:367-74.

18. Pope III CA, Thun MJ, Namboodiri MM, Dockery DW, Evans JS, Speizer FE, et al. Particulate air pollution as a predictor of mortality in a prospective study of U.S. adults. Am J Respir Crit Care Med 1995; 151:669-74.

19. Frampton MW, Utell MJ, Zareba W, Oberdörster G, Cox C, Huang LS, et al. Effects of exposure to ultrafine carbon particles in healthy subjects and subjects with asthma. Boston: Health Effects Institute; 2004.

20. Kim CS, Hu SC. Regional deposition of inhaled particles in human lungs: comparison between men and women. J Appl Physiol 1998; 84:1834-44.

21. Seaton A, MacNee W, Donaldson W, Godden D. Particulate air pollution and acute health effects. Lancet 1995; 345:176-8.

22. Bennett WD, Zeman KL, Kim C. Variability of fine particle deposition in healthy adults: effect of age and gender. Am J Respir Crit Care Med 1996; 153:1641-7.

23. Daigle CC, Chalupa DC, Gibb FR, Morrow PE, Oberdörster G, Utell MJ, et al. Ultrafine particle deposition in humans during rest and exercise. Inhal Toxicol 2003; 15:539-52.
24. Junger WL. Análise, imputação de dados e interfaces computacionais em estudos de séries temporais epidemiológicas [ $\mathrm{PhD}$ Dissertation]. Rio de Janeiro: Instituto de Medicina Social, Universidade do Estado do Rio de Janeiro; 2008.

25. Hastie TJ, Tibshirani RJ. Generalized additive models. New York: Chapman and Hall; 1990.

26. Conceição GMS, Saldiva PHN, Singer JM. Modelos MLG e MAG para análise da associação entre poluição atmosférica e marcadores de morbimortalidade: uma introdução baseada em dados da cidade de São Paulo. Rev Bras Epidemiol 2001; 4:206-19.

27. Braga ALF, Zanobetti A, Schwartz J. The lag structure between particulate air pollution and respiratory and cardiovascular deaths in 10 US cities. J Occup Environ Med 2001; 43:927-33.

28. Akaike $\mathrm{H}$. Information theory as an extension of the maximum likelihood principle. In: Petrov BN, Csaki F, editors. Second International Symposium on Information Theory. Budapest: Akadémiai Kiadó; 1973; p. 267-81.

29. Pope III CA, Burnett R, Thun MJ, Calle EE, Krewski D, Ito $\mathrm{K}$, et al. Lung cancer, cardiopulmonary mortality and long-term exposure to fine particulate air pollution. JAMA 2002; 287:1132-41.

30. De Leon SM, Thurston GD, Ito K. Contribution of respiratory disease to nonrespiratory mortality associations with air pollution. Am J Respir Crit Care Med 2003; 167:1117-23.

31. Lin CA, Pereira LAA, Conceição GMS, Kishi HS Milani Jr. R, Braga ALF, et al. Association between air pollution and ischemic cardiovascular emergency room visits. Environ Res 2003; 92:57-63.

32. Martins LC, Latorre MR, Saldiva PH, Braga ALF Air pollution and emergency room visits due to chronic lower respiratory diseases in the elderly: an ecological time-series study in Sao Paulo, Brazil. J Occup Environ Med 2002; 44:622-7.

33. Martins LC, Latorre MR, Cardoso MR, Gonçalves FL, Saldiva PH, Braga AL. Air pollution and emergency room visits due to pneumonia and influenza in Sao Paulo, Brazil. Rev Saúde Publica 2002; 36:88-94.

34. Frank R, Tankersley C. Air pollution and daily mortality: a hypothesis concerning the role of impaired homeostasis. Environ Health Perspect 2002; 110:61-5.

35. Meyer KC, Ershler W, Rosenthal NS, Lu XG, Peterson K. Immune dysregulation in the aging human lung. Am J Respir Crit Care Med 1996; 153:1072-9.

36. Leslie CA, Dubey DP. Increased PGE2 from human monocytes isolated in the luteal phase of the menstrual cycle. Implications for immunity? Prostaglandins 1994; 47:41-54.

37. Schwarz E, Schäfer C, Bode JC, Bode C. Influence of the menstrual cycle on the LPS-induced cytokine response of monocytes. Cytokine 2000; 12:413-6.

Submitted on 27/Jun/2010

Final version resubmitted on 14/Dec/2010

Approved on 29/Mar/2011 